\title{
Usefulness of the Anatomy Learning Comics and Anatomy Comic Strips to Adolescents
}

\author{
Utilidad de los Comics de Aprendizaje de Anatomía e \\ Historietas Cómicas de Anatomía para Adolescentes
}

\author{
Beom Sun Chung \& Min Suk Chung
}

CHUNG, B. S. \& CHUNG, M. S. Usefulness of the anatomy learning comics and anatomy comic strips to adolescents. Int. J. Morphol., 36(3):806-810, 2018.

SUMMARY: This study was intended to evaluate the anatomy comics as learning material for adolescents. For that, both the learning comics and comic strips were shown to 341 junior high school students who subsequently completed a questionnaire. According to the students answers, the anatomy comics were greatly or somewhat helpful in understanding anatomy (learning comics: $87.7 \%$; comic strips: $86.2 \%$ ). The anatomy comics were greatly or somewhat entertaining (learning comics: $66.9 \%$; comic strips: $77.4 \%$ ). According to their free remarks, the anatomy comics enhanced the students' understanding with the simple figures and easy explanations. The students regarded the anatomy comics as entertaining because of the related jokes and comparative daily lives. The students preferred the complimentary anatomy comics presented on the authors' homepage (anatomy.co.kr). This investigation proves the possibility that the anatomy comics contribute to adolescents learning.

\section{KEY WORDS: Adolescent; Nonprofessional education; Anatomy; Cartoons.}

\section{INTRODUCTION}

Knowledge of anatomy is likely to satisfy adolescents' curiosity and help them protect their own bodies, and this is why basic anatomy is taught to adolescents (Evans, 2007, 2013). Among anatomy learning contents, comics that are interesting and providing simplified information are more useful for young students (Reid \& Beveridge, 1986; McDermott, 1989; Tatalovic, 2009; Khalid et al., 2010; Song et al., 2013). The problem is that most existing anatomy comics are drawn by cartoonists who are ignorant of anatomy; their anatomy comics possess neither logical explanations nor suitable jokes (Clark, 2013; Kolpin, 2013). For the solution, the corresponding author of this article drew anatomy learning comics (briefly, learning comics) and anatomy comic strips (briefly, comic strips) and posted them at anatomy.co.kr. Both the Korean and English comics were created based on three decades of teaching experience (Hwang et al., 2005; Park et al., 2011; Kim et al., 2017).

In previous studies, the authors have administered questionnaire surveys and found that the learning comics were beneficial to the students in elementary school, high school, and medical school (Kim et al.); the comic strips were advantageous to the students in medical school (Shin et al., 2013). However, the studies on the two kinds of anatomy comics have been carried out separately, and so far, no research has studied the adolescents' reactions to both comics when the comics are presented together.

The purpose of this study was to determine the usefulness of the anatomy comics presented at anatomy.co.kr by gathering responses from junior high school students. For that, the corresponding author showed the 341 junior students the learning comics and comic strips, collected their responses by a questionnaire, and analyzed them.

\section{MATERIAL AND METHOD}

Two neighboring junior high schools asked the corresponding author to give a special lecture, and the author then suggested a lecture with anatomy comics that would take 40 minutes and a following questionnaire survey that would take 10 minutes. The two schools kindly agreed with the suggestion. 
The author gave the lectures in September and December 2016. During the lecture, the author showed the learning comics and comic strips he had been creating for 15 years (Fig. 1). He tried to explain both the educational value and humor of the comics. The author introduced the homepage, anatomy.co.kr, where the whole comics could be seen free of charge or registration.

After a question and answer session, the corresponding author explained this investigation to the attending students to obtain their participation in the survey. The students from both schools who agreed to participate (205 males and 136 females) completed the questionnaire anonymously. The students were mostly the same age, 12 years old.

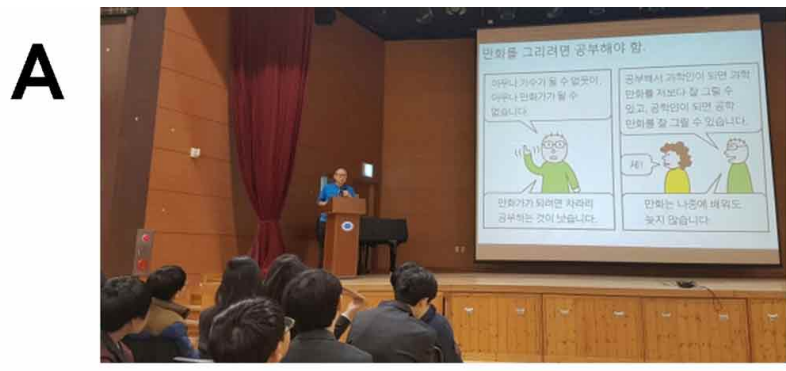

\section{B Or. Anastophoiol ms chung (anatomy.co.kr)}

Episode 29: Short legs in spite of tiptoe position

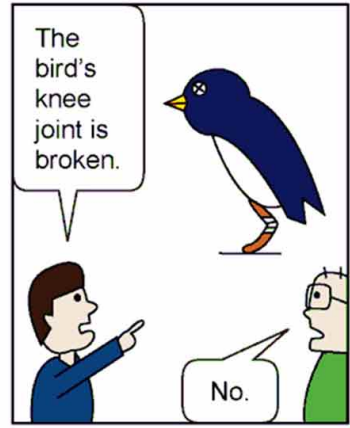

It must be the ankle joint because the joint is bulging posteriorly.
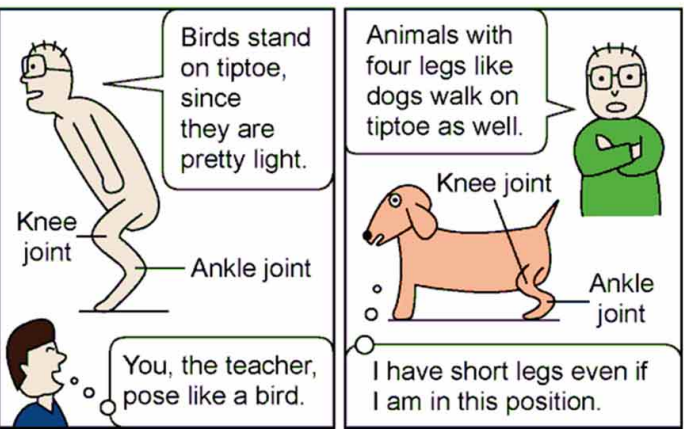

On the questionnaire, the students selected how helpful and interesting the learning comics and comic strips were. The author analyzed the between-sex difference through oneway ANOVA using Statistical Package for the Social Sciences (SPSS), version 20 (IBM Corp., Armonk, NY).

In response to the open-ended questions, the students freely described the strengths and weaknesses of the two types of comics.

The lecture slides, comics, and questionnaire were presented in Korean (Fig. 1A), and the students responded in Korean as well. Afterward, the Korean was translated into English for this report.

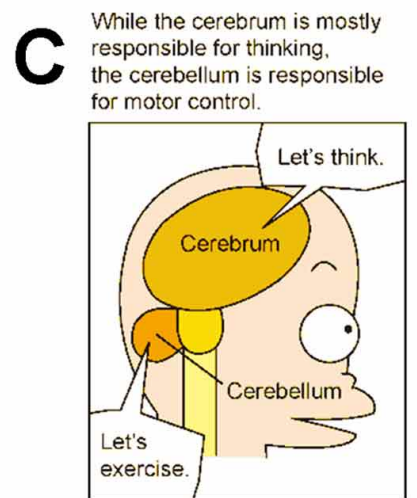

Motor activity ordered from the cerebrum is executed properly by the assistance of cerebellum.

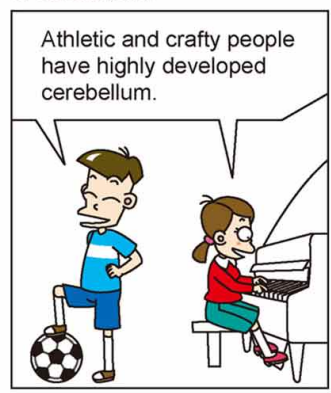

Specifically, the cerebellum enables one to balance.

contract muscle with appropriate force
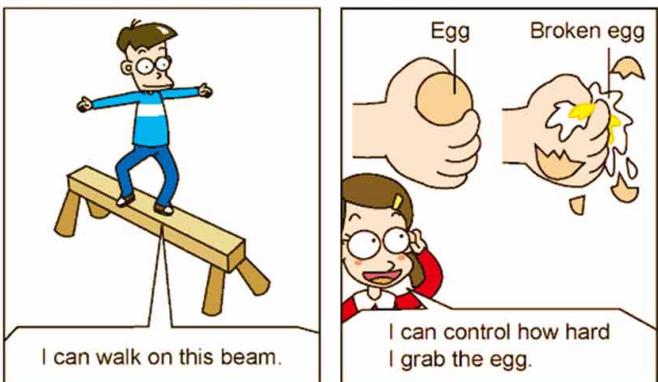

The human cerebellum is large than that of other animals, because only human is $\begin{array}{ll}\text { and execute motor activity } & \text { capable of performing } \\ \text { precisely. } & \text { such delicate activity. }\end{array}$

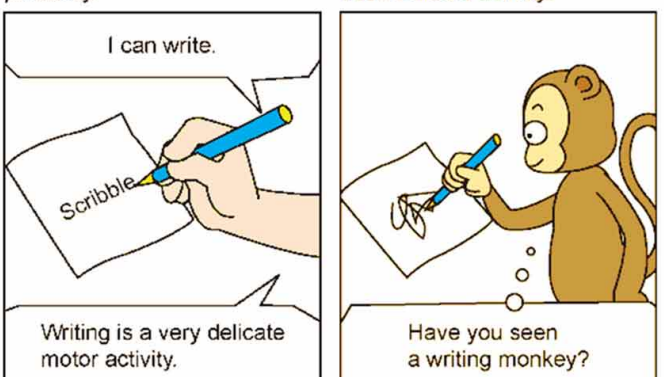

Fig. 1. The corresponding author's anatomy lecture (A) showing the comics strips (B) and the learning comics (C). In the lecture, the Korean comics are demonstrated; in the article, their English versions are exhibited. 


\section{RESULTS}

The selective questionnaire survey displayed the following results: The students who answered that the learning comics were greatly or somewhat helpful in understanding anatomy $(87.7 \%)$ were as much as those who answered that the comic strips were greatly or somewhat helpful $(86.2 \%)$ (Fig. 2A). Concerning the helpfulness of the anatomy comics, there was no significant gender difference.

The students who answered that the learning comics were greatly or somewhat entertaining $(66.9 \%)$ were less than those who answered that the comic strips were greatly or somewhat entertaining (77.4\%) (Fig. 2B). Male students had more fun than female students, with the learning comics (one-way ANOVA, F = 5.451, $\mathrm{P}=0.020$ ) and with the comic strips (one-way ANOVA, $\mathrm{F}=5.411, \mathrm{P}=0.021$ ).
The students free comments could be categorized into the helpfulness, entertainingness, and so on (Table I).

According to the remarks, the comics were helpful for understanding anatomy because of the simple figures and easy explanations. However, there were contrasting opinions because of the difficult anatomy terms and complicated topics (Table I).

In general, the students regarded the comics as entertaining because of the jokes related to daily lives. However, the comics did not entertain all students because of the unsatisfactory plots and characters (Table I).
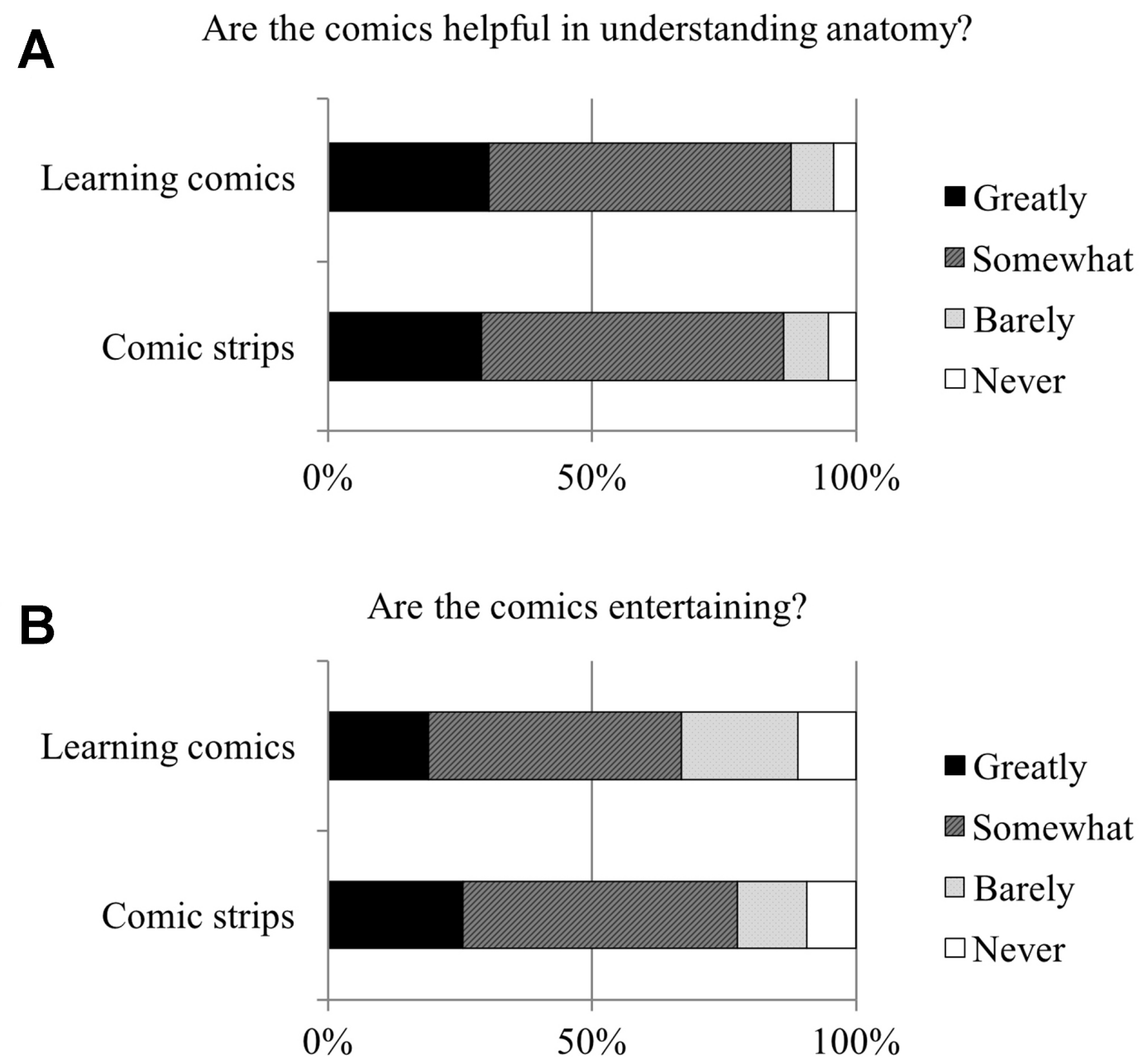

Fig. 2. Survey results regarding the helpfulness (A) and entertainingness (B) of the anatomy comics from 341 junior students. 
Table I. Free comments on the learning and comic strips from 341 junior students. Similar comments are aggregated, and the total numbers of comments are displayed. Weaknesses of the comics are indicated with asterisks $(*)$.

\begin{tabular}{|c|c|c|}
\hline & Learning comics & Comic strips \\
\hline \multicolumn{3}{|l|}{ Helpfulness } \\
\hline (A) Simple figures were helpful for understanding anatomy. & 37 & 21 \\
\hline (B) Easy explanations were help ful for understanding anatomy. & 26 & 17 \\
\hline $\begin{array}{l}\text { (C) Difficult terms that were different from everyday lan guage were not } \\
\text { helpful for understanding anatomy.* }\end{array}$ & 24 & 25 \\
\hline $\begin{array}{l}\text { (D) Some episodes of the comics that dealt with complicated topics were not } \\
\text { help ful for understanding anatomy.* }\end{array}$ & 0 & 6 \\
\hline \multicolumn{3}{|l|}{ Entertainingness } \\
\hline (E) Anatomy jokes themselves were entertaining. & 54 & 79 \\
\hline (F) Correlating anatomy with common peoples daily lives was entertaining. & 48 & 66 \\
\hline (G) Medical students' daily lives were entertaining. & 0 & 8 \\
\hline (H) Comics had no interesting plot, unlike ordinary comics.* & 19 & 6 \\
\hline (I) Main characters were not as entertaining as ordinary comics character s.* & 5 & 7 \\
\hline \multicolumn{3}{|l|}{ Etc. } \\
\hline (J) It was convenient to watch the comics on a smart phone. & 24 & 15 \\
\hline
\end{tabular}

\section{DISCUSSION}

The present study aimed to determine the usefulness of the learning comics and comic strips to groups of adolescents.

In the free comments, the students found the learning comics helpful for understanding anatomy because they were simply drawn and explained (Table I. A-B). Another reason might have been the learning comics' properties: They were well arranged in long sequences according to the body systems, such as 94 frames for the nervous system (Kim et al.) (Fig. 1B).

The survey responses showed that the comic strips were nearly as helpful for anatomy comprehension as the learning comics (Fig. 2A), which could have been because the comic strips provided ways to remember anatomy contents (Shin et al.) (Fig. 1B).

As expected, the comic strips were superior to the learning comics in terms of being entertaining (Table I: EG) (Fig. 2B). Unlike the characters in the learning comics, who only delivered anatomy knowledge (Fig. 1C), the characters in the comic strips gave humorous comments about the various situations (Fig. 1B) (Park et al.). Nevertheless, the characters were less interesting than the characters in commercial comics (Table I. I).

The male students found the comic strips more entertaining than the female students. Even in another study, there was a tendency that male students were more favorable for humorous science comics than female students (Lyness, 1951).
Some of the students disliked the anatomy terms in the comics because they did not correlate with everyday words (e.g., "patella" rather than "knee cap") (Table I. C). The corresponding author had faithfully followed the official anatomical terms in Korean and English because the initial target of the comics was medical students, who must know the exact terms (Park et al.; Kim et al.).

The responses from the adolescent students and the medical students could be compared. Among the free comments of the young students, they preferred the comics' fun (Table I. E-G) to their usefulness (Table I. A-B), whereas the medical students emphasized the usefulness because they had to pass their anatomy courses (Shin et al.). The young students generally like the simplified anatomy figures and stories (Table I. A-B), whereas the many medical students felt the simplified contents were insufficient (Shin et al.). The young students complained about the plots and characters (Table I. H-I), whereas the medical students did not (Shin et al.).

Although all comics were devised and written by the corresponding anatomists, the learning comics (Fig. 1C) and comic strips (Fig. 1C) were drawn by professional cartoonists and amateur cartoonists (the corresponding author and his colleagues), respectively. Therefore, the authors expected different responses to the different drawing expertise levels. However, none of the students mentioned this difference; the more elaborate illustrations did not appear to considerably influence the responses.

The junior high students preferred the complimentary anatomy comics that were presented online. They considered it convenient to watch the comics on smart phones (Table I. J) because each row of the comics contains two frames (Fig. 1B, 1C). 
For adolescents' anatomy learning, their instructors may appropriately arrange the learning comics and comic strips in their lecture slides or other learning materials. Regarding the comic strips, hundreds of episodes are currently available, so that suitable ones can be selected (Shin et al.).

Additionally, the authors recommend integrating the anatomy comics with multimedia contents. An example is the authors software (Memory Booster of Basic Anatomy) that is available on the same site; in this software, the comics containing only schematic drawings are compensated with the two-dimensional and three-dimensional images that present realistic features of the human body (Chung et al., 2017).

The anatomy comics at anatomy.co.kr potentially contribute to adolescents learning. The anatomy knowledge in the comics seems to enable the junior high school students in this study to satisfy their curiosity and preserve their body health. In addition, through the learning comics, young students can review the biology contents overlapped with the anatomy contents, such as the four chambers of heart. Through the comic strips, the students can comprehend the medical students' lives and maybe consider medical school in their own futures (Table I. G).

\section{ACKNOWLEDGEMENTS}

This research was financially supported by the Ministry of Trade, Industry and Energy (MOTIE) and Korea Institute for Advancement of Technology (KIAT) through the International Cooperative R\&D program (Grant number: N0002249).

CHUNG, B. S. \& CHUNG, M. S. Utilidad de los comics de aprendizaje de anatomía e historietas cómicas de anatomía para adolescentes. Int. J. Morphol., 36(3):806-810, 2018.

RESUMEN: El objetivo de este estudio fue evaluar los cómics de anatomía como material de aprendizaje para adolescentes. Para eso, tanto los cómics de aprendizaje como las tiras cómicas se mostraron a 341 estudiantes de secundaria que posteriormente completaron un cuestionario. De acuerdo con las respuestas de los estudiantes, los cómics de anatomía fueron de gran utilidad o algo útiles para comprender la anatomía (cómics de aprendizaje: $87,7 \%$; historietas: $86,2 \%$ ). Los cómics de anatomía fueron muy entretenidos (cómics de aprendizaje: 66,9\%; historietas: 77,4 \%). De acuerdo con sus comentarios, los cómics de anatomía mejoraron la comprensión de los estudiantes con figuras simples y explicaciones fáciles. Los estudiantes consideraron los cómics de anatomía como entretenidos debido a los chistes relacionados y la comparación con la vida diaria. Los estudiantes prefirieron los cómics de anatomía complementarios presentados en la página principal de los autores (anatomy.co.kr). Esta investigación demuestra la posibilidad de que los cómics de anatomía contribuyan al aprendizaje de los adolescentes

PALABRAS CLAVE: Adolescente; Educación no profesional; Anatomía; Caricaturas.

\section{REFERENCES}

Chung, B. S.; Kim, J. \& Chung, M. S. Integrated comics and Visible Korean movies for laypeople's learning of systemic anatomy. Int. J. Morphol., 35(3):883-7, 2017.

Clark, K. A Tour of Your Muscular and Skeletal Systems. North Mankato, Capstone Press, 2013.

Evans, D. J. Connecting with different audiences: the anatomy of communication is essential. Anat. Sci. Educ., 6(2):134-7, 2013.

Evans, D. J. R. The role of the anatomist in communicating anatomy to a lay audience. Eur. J. Anat., 11 (S1):79-83, 2007.

Hwang, S. B.; Chung, M. S. \& Park, J. S. Anatomy cartoon for common people. Korean J. Anat., 38(5):433-41, 2005.

Khalid, H.; Meerah, T. S. \& Halim, L. Teachers' perception towards usage of cartoon in teaching and learning physics. Procedia Soc. Behav. Sci., 7:53845, 2010.

Kim, J.; Chung, M. S.; Jang, H. G. \& Chung, B. S. The use of educational comics in learning anatomy among multiple student groups. Anat. Sci. Educ., 10(1):79-86, 2017

Kolpin, M. A Tour of Your Nervous System. North Mankato, Capstone Press, 2013.

Lyness, P. I. Patterns in the mass communications tastes of the young audience. J. Educ. Psychol., 42(8):449-67, 1951.

McDermott, T. J. Cartooning: a humorous approach to medical and health education. J. Biocommun., 16(4):20-7, 1989.

Park, J. S.; Kim, D. H. \& Chung, M. S. Anatomy comic strips. Anat. Sci. Educ., 4(5):275-9, 2011.

Reid, D. J. \& Beveridge, M. Effects of text illustration on children's learning of a school science topic. Br. J. Educ. Psychol., 56(3):294-303, 1986.

Shin, D. S.; Kim, D. H.; Park, J. S.; Jang, H. G. \& Chung, M. S. Evaluation of anatomy comic strips for further production and applications. Anat. Cell Biol., 46(3):210-6, 2013.

Song, J. J.; Lee, H. C. \& Yoo, P. K. The effect of science cartoon reading on the levels of interest in science, the academic achievements and the scientific attitudes of elementary students. J. Korean Elem. Sci. Educ., 32(4):581-92, 2013.

Tatalovic, M. Science comics as tools for science education and communication: a brief, exploratory study. J. Sci. Commun., 8(4):1-17, 2009 .

Corresponding author:

Min Suk Chung

Department of Anatomy

Ajou University School of Medicine

164 Worldcup-ro

Suwon 16499

REPUBLIC OF KOREA

E-mail: dissect@ajou.ac.kr

Received: 16-01-2018

Accepted: 29-03-2018 